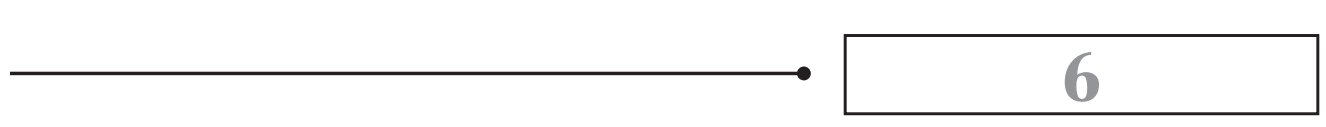

\title{
DA PARTILHA DAS RECEITAS PETROLÍFERAS
}

\subsection{NOTAS INTRODUTÓRIAS}

Após ingressarem nos cofres do Tesouro Nacional, as receitas públicas pagas a título de royalties lato sensu pelas companhias petrolíferas deverão ser distribuídas aos beneficiários eleitos pela legislação, em obediência ao artigo 20, parágrafo $1^{\circ}$, da Constituição Federal. Uma parte permanecerá com a União, e outra será destinada a Estados e Municípios, notadamente aqueles em cujo território sejam desenvolvidas atividades extrativas.

Nesse contexto, o objetivo do presente capítulo será analisar a forma como o ordenamento jurídico tratou a partilha dos royalties lato sensu, iniciando pela análise do comando constitucional, para, em seguida, verificar, em detalhes, como a legislação ordinária operacionalizou essa repartição.

Contudo, em um primeiro momento, expõem-se os principais argumentos econômicos contra e a favor da descentralização das rendas petrolíferas, debatidos na doutrina nacional e internacional, observando em que medida é eficiente que estas receitas permaneçam nos entes locais ou regionais, ou se devem ser concentradas no governo federal. Tais informações serão importantes, pois conferem ao jurista uma visão crítica ao interpretar as normas que tratam do assunto, auxiliando-o a compreender o fenômeno da repartição de receitas de uma maneira mais global, percebendo os impactos dos seus posicionamentos para a economia do país.

\subsection{FEDERALISMO FISCAL E PARTILHA DE RECEITAS ORIUNDAS DE RECURSOS NATURAIS}

Cada país produtor de petróleo possui um regramento bastante peculiar no que tange à forma como as receitas públicas arrecadadas com a atividade petrolífera serão 
distribuídas internamente. São vários os fatores que podem influenciar na construção de um modelo próprio de alocação dessas rendas: questões históricas, econômicas, sociais e até mesmo religiosas.

Existe uma enorme gama de possibilidades, algumas marcadas por medidas que centralizam as receitas no governo federal, enquanto outras se baseiam em uma maior descentralização, atribuindo mais poder aos entes subnacionais onde estão presentes os recursos naturais. No entanto, tanto em um como noutro caso, existem problemas a serem enfrentados pelos Estados nacionais, que se acentuam sobremaneira no caso de uma federação, onde cada ente subnacional, dotado de autonomia política, administrativa e financeira, busca defender interesses próprios, os quais, muitas vezes, não guardam compatibilidade com os dos demais. Por exemplo, uma descentralização das rendas que privilegie as regiões produtoras gera uma disparidade econômica inter-regional, sobretudo em países com grandes dimensões. Ao revés, afirma-se que uma centralização desses recursos dificultaria os entes locais de promoverem medidas adequadas de prevenção e combate a danos ambientais gerados pela atividade petrolífera.

O estudo de todos esses possíveis arranjos financeiros que se formam dentro de uma federação, de modo a distribuir receitas e encargos entre os seus entes, é o que se pode chamar de federalismo fiscal. O Prof. José Mauricio Conti define-o nos seguintes termos:

O estudo da maneira pela qual as esferas de governo se relacionam do ponto de vista financeiro, que podemos denominar de federalismo fiscal, engloba a análise da maneira pela qual está organizado o Estado, qual é o tipo de federação adotado, qual é o grau de autonomia dos seus membros, as incumbências que lhes são atribuídas e, fundamentalmente, a forma pela qual serão financiadas (2001, p. 24-25).

O objetivo do federalismo fiscal, segundo Marcos Mendes, é "buscar uma divisão de tarefas que maximize a eficiência do setor público". Prossegue sua explanação afirmando que "o federalismo fiscal procura estabelecer parâmetros de racionalidade e eficiência econômica que orientem os ajustes na organização das federações, à medida que o processo político permita tais alterações" (2004, p. 421-423).

Assim, o objetivo da presente seção consiste em expor os principais argumentos econômicos contra e a favor da descentralização das rendas petrolíferas, debatidos na doutrina internacional, verificando em que medida estas receitas devem permanecer nos entes locais ou regionais ou se devem ser concentradas no governo federal. Antes, porém, analisam-se as principais técnicas utilizadas para levar a cabo a descentralização dessas receitas apontadas por Charles E. McLure (2003) e Giorgio Brosio (2003), que consideraram em sua análise tanto Estados federais como unitários. 
Ensina McLure que, de maneira geral, observam-se cinco formas por meio das quais isso é feito: a) transferência da propriedade dos recursos para os entes subnacionais; b) atribuição ao ente subnacional de competência para legislar, implementar e arrecadar as receitas petrolíferas, notadamente dos royalties; c) surcharges; d) tax sharing; e e) revenue sharing.

No primeiro, a propriedade dos recursos naturais é atribuída ao ente subnacional, de modo que o total das receitas arrecadadas com a atividade petrolífera é por ele apropriado, estando livre para decidir sobre todos os aspectos da cobrança (ex.: base de cálculo, alíquota, sujeito passivo etc.), bem como para arrecadar, gerir e fiscalizar a sua aplicação.

No segundo caso, embora a propriedade dos recursos seja do ente central, os entes subnacionais onde o petróleo está localizado detêm o poder de legislar, instituir e administrar as receitas tributárias ou não, percebidas em decorrência do exercício da atividade petrolífera no seu território. Contudo, essa liberdade não é plena como no sistema anterior, podendo encontrar certas limitações na ordem constitucional ou em leis nacionais:

This is the situation in the United States and Canada. Subnational taxing powers may be exclusive or concurrent with national powers, and constitutions or national laws may limit such legal rights. For example, there may be limits on the types of taxes subnational governments can impose on oil, on tax rates, and even on the definition of the tax base. For example, it might be required that key provisions such as depletion allowances follow national law, or the required conformity might be more far-reaching (McLURE, 2003, p. 206).

Aduz-se também ser comum que, neste caso, existam comandos impondo a uniformização de procedimentos concernentes ao compliance e à administração das receitas em questão, uma vez que a ausência de disposições neste sentido levaria à criação de lacunas e sobreposições de obrigações acessórias na base tributária dos Estados, gerando um custo excessivo tanto para os contribuintes como para os entes públicos.

A terceira técnica a que faz referência o autor são as subnational surcharges on national taxes, ou seja, o compartilhamento de uma mesma base de cálculo pelos entes subnacional e central, sendo a alíquota total incidente resultante da soma da alíquota imposta por cada um desses entes. Essa forma de arrecadação é utilizada por algumas províncias no Canadá e se dá nos seguintes termos:

Subnational governments may collect surcharges on the national tax, or the national government may collect surcharges on the national tax, or the national government may collect surcharges for them. Federal administration of provincial income tax surcharges is available on a voluntary basis to Canadian provinces that choose to adopt the federal income tax base. Other provinces, while administering their own taxes, rely heavily on the federal definition of taxable income. 
Subnational surcharges may be imposed on either the national tax base or the national tax liability. Subnational autonomy is greater if the surcharge is levied on the national tax base than if it is levied on the amount of the national tax, as in Canada until recently. In the latter case the structure of subnational taxes depends on the structure of the national tax (2003, p. 207).

A quarta forma de participação dos entes nacionais nas receitas petrolíferas é a chamada tax sharing, na qual, embora as receitas sejam arrecadadas pelo ente central, são posteriormente repassadas aos entes onde se localiza a produção, segundo alíquotas definidas na legislação nacional. Este mecanismo é similar ao que ocorre no Brasil, por exemplo, no caso do Imposto sobre a Propriedade Territorial Rural, cuja competência para arrecadá-lo pertence à União, que tem o dever de repassar diretamente ao município onde estiver localizado o imóvel, $50 \%$ (cinquenta por cento) do que arrecadar. Com isso, assim como nas demais técnicas comentadas, as receitas oriundas da atividade petrolífera permanecem no ente onde ocorre a extração.

Por fim, tem-se o modelo de revenue sharing, no qual "as receitas são partilhadas com as jurisdições subnacionais com base em uma fórmula, em vez de serem canalizadas diretamente para as suas jurisdições de origem" (McLURE, 2003, p. 207, tradução nossa). Este é o modelo adotado no Brasil e pela maioria dos países produtores de petróleo, segundo informa Giorgio Brosio, mencionando outros, também organizados sob a forma federativa, que adotam a técnica em comento: Austrália, Argentina, Rússia e Canadá (nas regiōes de Newfoundland e Labrador, abrangidas pelo Acordo do Atlântico). Além desses, adotam também tal sistema países unitários, tais como Colômbia, Bolívia, Papua Nova Guiné e Itália (BROSIO, 2003, p. 257).

Segundo o autor italiano, uma sexta forma de se transferir receitas para os entes subnacionais tem sido desenvolvida recentemente em Papua Nova Guiné, conhecida por in-kind revenue sharing. Nesta, os entes subnacionais onde se localizam atividades extrativas têm acesso a uma parcela da receita gerada em seu território com a atividade petrolífera, mediante o fornecimento de infraestrutura pelas companhias que exploram esses recursos e segundo determinado pela legislação nacional. Enfatiza, por fim, ao se referir às três últimas técnicas mencionadas, que a utilização de uma não exclui a de outra em um mesmo país, havendo diversos exemplos em que elas são combinadas.

Visto isso, passa-se a analisar os argumentos econômicos contra e a favor da descentralização, formulados pela doutrina ${ }^{47}$ sobre o tema.

(TER-MINASSIAN, 1997), (BROSIO, 2003), (McLURE, 2003), (BAHL, 2004), (AHMAD; MOTTU, 2003), (MENDES, 2012), (SPRINGER, 2008) e (SERRA, 2006). 
O primeiro deles, a favor, é chamado de "o argumento hereditário". Afirma-se que os entes regionais e a sua população receberam uma herança na forma de recursos naturais, e que se esta vai se esgotar no futuro, necessitará ser reposta de alguma forma. Assim, o dinheiro obtido com os recursos naturais deveria ser investido na diversificação produtiva, garantindo às gerações futuras daquele local uma base de sustentação econômica.

O segundo argumento está ligado a um custo de reembolso. A região que abriga atividades extrativas de recursos naturais estaria sujeita a degradações ambientais. Precisaria também investir em infraestrutura para dar suporte à atividade, bem como sofre transtornos sociais causados pelo aumento da população. Assim, teria direito de receber as receitas decorrentes dessa exploração como um reembolso pelas despesas geradas em seu território.

A terceira justificativa para a razão de os recursos naturais deverem permanecer nos entes regionais ou locais baseia-se na necessidade de evitar que estes implantem mecanismos indesejáveis para a obtenção de receitas, conhecidos como backdoor. Aduz-se que se não houver um sistema formal de reembolso, vários tipos de taxas despropositadas serão criadas, o que gerará um problema para aqueles que desejam investir na região.

Por fim, menciona-se também a importância da transferência desses recursos para as regiōes produtoras, como uma forma de manutenção da unidade política, que depende de um modelo de repartição de receitas aceito como justo por todas as regiões, ainda quando não lhes seja absolutamente favorável.

Quanto aos argumentos contra a descentralização, o primeiro deles baseia-se em questões de equalização fiscal e justiça redistributiva. Tendo em vista que os recursos naturais são geograficamente concentrados, a alocação das receitas apenas nas regiôes produtoras promoveria uma significativa diferença de renda per capita entre os entes federativos, o que se refletiria na qualidade dos serviços públicos prestados, situação indesejada, sobretudo em países como o Brasil, onde a diminuição das desigualdades regionais e sociais é um objetivo constitucionalmente fixado.

Outro forte argumento é o de que os governos subnacionais não têm capacidade para suportar as altas oscilações por que passa o preço do petróleo, o que se reflete diretamente no montante da receita arrecadada. Dessa forma, os governos nacionais estariam em uma posição mais confortável para lidar com essa instabilidade do que os governos subnacionais, por exemplo, porque teriam um maior orçamento, no qual haveria uma menor porcentagem de participação das receitas petrolíferas, além de terem um maior acesso ao mercado de créditos e o poder de controle sobre a política monetária. Some-se ainda, argumentam os autores, o fato 
de o ente central estar normalmente mais bem equipado técnica e politicamente, bem como resistir melhor à pressão por gastos quando as receitas estão altas, de modo a implementar políticas anticíclicas e estabilizadoras, conforme exemplifica o Fundo Petrolífero Estatal Norueguês (FPEN).48

Dessa forma, conclui Springer:

o mais eficiente seria deixar sob responsabilidade da União a arrecadação das receitas oriundas do petróleo, bem como dos gastos. Caso se entenda que seja necessário redistribuir os recursos para os entes federativos, deveria ser criada uma fórmula que garantisse um fluxo relativamente constante de receitas para esses entes. Com esse sistema, a volatilidade das receitas advindas da exploração do petróleo seria transferida, na medida do possível, integralmente para a União (2009, p. 34).

O terceiro argumento diz respeito a questões macroeconômicas. Para Bahl, impostos mais elevados sobre os recursos naturais podem resolver o problema do déficit nacional, o que ajudaria a manter a carga tributária do país menor. Além disso, o deslocamento de receitas para o governo nacional the daria uma maior margem de manobra para orientar investimentos.

Como último argumento, afirma-se que os governos locais tendem a desperdiçar o dinheiro arrecadado com os recursos naturais, uma vez que não teriam capacidade para absorver uma quantidade tão grande de dinheiro em tão pouco tempo, o que levaria os seus líderes a gastar o dinheiro arrecadado em atividades que não beneficiem as gerações futuras, ou a investirem fortemente no aumento das despesas correntes do governo, além de propiciar o aumento da corrupção.

Ao expor tais argumentos, concluem os autores no sentido de que, em um sistema ideal, seria desejável a centralização das receitas petrolíferas, juntamente com a transferência de recursos financeiros para os entes subnacionais, com fundamento em outras bases tributárias, de forma a promover políticas fiscais distributivas e

48 "Trata-se de um fundo com dupla finalidade: a garantia de estabilidade macroeconômica e a constituição de um fundo de poupança. A contribuição do fundo para a estabilidade macroeconômica se efetiva em duas frentes: nos momentos de alta do preço do petróleo, o fundo, ao recolher o excesso de divisas daquele grande país exportador, contribuiria para minimizar a pressão inflacionária; nas conjunturas de baixa do preço do petróleo, o fundo socorreria o Tesouro, evitando um maior nível de endividamento. Portanto, um fundo voltado para a estabilidade monetária e para prevenção de déficits públicos.

A função de poupança é realizada a partir dos depósitos anuais, em conjunturas de alta dos preços petrolíferos, e do incremento de dividendos ao principal do fundo. Este fundo de poupança torna-se especialmente relevante para o país, diante da previsão (em função do envelhecimento da população e do amadurecimento dos campos petrolíferos noruegueses) de incremento das despesas com aposentadoria na mesma época em que, espera-se, as receitas petrolíferas começarão a cair." (SERRA, 2005, p. 133-134). 
equalizadoras. Contudo, diante das dificuldades políticas ${ }^{49}$ que envolvem a sua efetivação, a solução menos indesejada seria a transferência das rendas petrolíferas via sharing revenues, por meio da qual é possível realizar a transferência de recursos segundo critérios pre-estabelecidos pela legislação nacional, os quais podem conter medidas redistributivas, bem como impor o alcance de resultados na aplicação dos recursos.

Analisando especificamente o caso brasileiro, Serra (2003), Springer (2009) e Mendes e Kohler (2012) concluem no mesmo sentido, alertando para a inaplicabilidade, no caso do Brasil, dos argumentos apresentados a favor de políticas descentralizadoras.

\subsection{EXPOSIÇÃO DO DEBATE POLÍTICO NO BRASIL SOBRE A PARTILHA DOS ROYALTIES}

A partir da descoberta do pré-sal, instaurou-se no cenário político brasileiro uma ampla discussão acerca da forma como são distribuídas as receitas petrolíferas no Brasil. O cerne da disputa referia-se à revisão dos critérios de partilha dos royalties lato sensu, transferidos pela União aos entes subnacionais, pois, enquanto os entes produtores defendiam um direito constitucional a se apropriar de uma maior parcela dos royalties transferidos, os demais Estados e Municípios argumentavam que por ser um bem público da União, o petróleo deveria beneficiar igualmente toda a federação.

Uma análise jurídica detalhada dos critérios previstos na legislação para operar essa divisão será feita adiante, à luz das proposições descritivas a serem formuladas com relação ao conteúdo do parágrafo $1^{\circ}$ do artigo 20 da Constituição Federal, dispositivo que rege a transferência das receitas petrolíferas entre os entes federativos no Brasil. Por ora, tal qual se fez no tópico anterior, tão só serão expostos os argumentos econômicos a favor e contra a descentralização dos recursos formulados pela doutrina, agora especificamente para o caso brasileiro, que, segundo os autores analisados, devem guiar o debate político na formulação do novo regime de partilha.

49 "The analysis presented here is best applied before oil is discovered. In that context, decisions on revenue assignment can be made behind the veil of ignorance, not knowing how much revenue will be at stake or which will be the oil-rich jurisdictions. Regional vested interests will not yet have arisen and a nationally oriented view of costs of compliance and administration, of distributional equity, and of allocative efficiency is possible. Once oil has been discovered, the political dynamic is likely to be very different. If reserves are extremely valuable, and especially if they are highly concentrated geographically, regional interests will come to the fore and a different view of distributional issues - the distribution of revenues between the central and subnational governments and among subnational governments - is likely to dominate all other issues in political discussions. When the stakes are high, such discussions may become especially acrimonious" (McLURE, 2003, p. 204-205). 
Segundo José Roberto Afonso, há um consenso atualmente no Brasil sobre a essencialidade de se discutir - ou rediscutir - o destino que a nação vai dar às futuras receitas advindas da exploração do petróleo presente na sua plataforma continental. Entende ele que o ponto de partida para tais debates deveria ser o destino dado às presentes receitas e, com base nisso, discutir os princípios que devem nortear as regras de distribuição e aplicação das rendas do petróleo. Assim se posiciona:

Esse debate não pode girar apenas em torno do pretenso direito natural (ou constitucional) de propriedade das distintas esferas de governo sobre as jazidas de petróleo, mas deve se pautar pelo princípio da justiça entre geraçōes proposto por Hartwick (1977). Ou seja, o ideal é que as decisões de políticas públicas em torno da matéria tenham por objetivo básico proporcionar às geraçôes futuras uma compensação pela exploração presente de um recurso exaurível, o que pode ser feito sob diversas formas de poupança e investimento (AFONSO, 2008, p. 233)

Conforme exposto na seção anterior, um argumento muito utilizado por aqueles que defendem a transferência das receitas petrolíferas para as regiões produtoras é que estas necessitam ser compensadas pelos danos ambientais sofridos em seu território com o exercício da atividade extrativa, bem como para arcar com o aumento da demanda por obras de infraestrutura e serviços públicos. Aduz Kiyoshi Harada:

Realmente, não há como negar que a exploração de recursos naturais, que se caracteriza como atividade de grande porte, obriga os poderes públicos a efetuar investimentos maciços na formação de completa infra-estrutura material e pessoal, capaz de suportar as movimentaçóes de bens e pessoas delas decorrentes. Além disso, notadamente o poder público local é obrigado a manter um programa ou um serviço de assistência à população direta ou indiretamente envolvida na atividade econômica da espécie. É fato incontestável que toda atividade econômica de grande porte atrai populações mais carentes, resultando na formação de cinturões de pobreza em torno dos centros urbanos, que se constituem em causas permanentes de inúmeros problemas.

Em caso de acidentes, decorrentes dessas atividades, torna-se imperiosa a imediata mobilização de recursos materiais e humanos pelos poderes públicos. E o poder público local é sempre aquele que se encontra na linha de frente para prestar os primeiros socorros à população atingida (2009, p. 85)

$\mathrm{O}$ argumento faz sentido, contudo, precisa ser bem mais ponderado, sobretudo no caso brasileiro, uma vez que mais de $90 \%$ da produção nacional de petróleo ocorre na plataforma continental, na sua maioria, a uma distância superior a 100 milhas da costa. Em decorrência disso, o simples fato de um município ser considerado confrontante não implica que este sofra algum impacto com a atividade: 
No caso da produção em mar, entretanto, a definição das localidades com direito à compensação é absolutamente arbitrária e tem se baseado em um conceito acessório, o da "confrontação" com poços ou campos de petróleo, ainda que esses poços e campos estejam - na sua maioria - a uma distância de quase 100 milhas da costa, onde diferentes prolongamentos de linhas podem implicar diferentes situações de "direito à compensação" (AFONSO, 2008, p. 240).

No mesmo sentido, Serra ilustra essa questão referindo-se ao Município de Campos dos Goytacazes:

Tome-se, como exemplo, o município de Campos dos Goytacazes cujas projeções traçadas pelo IBGE abarcam quase a totalidade dos poços da Bacia de Campos, garantido a esse município $24,3 \%$ do total pago a todos os municípios (...), embora as atividades de embarque e desembarque associadas à atividade petrolífera sejam pouco expressivas em seu território (2006, p. 218).

Com base em tais argumentos, concluem que uma repartição justa das receitas petrolíferas seria aquela em que fossem beneficiadas as regióes realmente afetadas, e não aquelas que simplesmente se encontram mais próximas dos campos de extração.

Ademais, se a transferência de receitas para as ditas regiões produtoras são devidas em razão de um dano, os valores repassados pela União não poderiam estar vinculados a uma fração do que for produzido pela empresa concessionária. Haveria, necessariamente, um teto, que seria exatamente o valor desse dano.

Serra propõe a implementação de um teto ao valor dos royalties e participações especiais repassados pela União aos entes subnacionais, como sugestão para o aprimoramento das regras de distribuição e aplicação das rendas petrolíferas:

A norma brasileira de distribuição das rendas petrolífera entre os municípios não prevê nenhum mecanismo de limitação das somas máximas de repasses para estas esferas governamentais. A questão que parece nortear este debate, é: será que o aumento do volume de petróleo e gás extraído da plataforma continental gera impactos proporcionais no território continental?

É possível que a elevação da demanda por alguns insumos produtivos cresça proporcionalmente ao volume de petróleo e gás extraído, mas grande parte dos bens e serviços que atendem ao segmento de E-P, como é sabido, sofrerão somente acréscimos marginais em sua demanda, ou permanecerão fixos, até certo limite, como por exemplo, a infra-estrutura de dutos de escoamento.

Uma definição de tetos máximos para os repasses de royalties aos municípios, estabelecidos em razão do volume produzido, poderia servir como parâmetro para uma lógica de distribuição mais equânime. No Estado de Dakota do Norte (EUA), por exemplo, são utilizadas regras para limitação do volume de recursos destinados às esferas locais (2006, p. 234). 
Marcos Mendes e Marcos Kohler afirmam que a própria atividade petrolífera estimula bastante o desenvolvimento de atividades econômicas nas regiões afetadas, "aumentando substancialmente a base de arrecadação tributária" (2012, p. 2). Defendem que:

No que diz respeito aos impactos ecológicos, a distância entre os campos do pré-sal e a costa, de centenas de quilômetros, torna praticamente impossível associar qualquer dano ecológico ao município confrontante: o município efetivamente afetado dependerá muito mais das correntes marítimas e de outros fatores geológicos do que da proximidade da plataforma de exploração $(2012$, p. 2).

Como visto, mesmo os argumentos a favor da descentralização apontados na doutrina internacional são vistos com uma série de ressalvas pela doutrina econômica brasileira, em face da peculiaridade existente em nosso território, consistente no fato de a produção de petróleo se dar em sua imensa maioria na modalidade offshore.

No que tange aos argumentos contra a descentralização dos recursos, critica-se severamente a alta concentração da renda petrolífera em um único Estado brasileiro - o Rio de Janeiro - e em um pequeno número de municípios, localizados nesse Estado.

Essa concentração pode ser verificada com a análise dos valores arrecadados no ano de 2011 com royalties e participações especiais. Dos 8.907 bilhões de reais arrecadados a título de royalties e participações especiais destinados aos Estados brasileiros, 6.949 bilhões de reais ingressaram nos cofres do estado do Rio de Janeiro, o que corresponde a cerca de $78 \%$ (setenta e oito por cento) do total. Na esfera municipal, dos 5.632 bilhões de reais destinados a essas unidades da federação, 3.766 bilhōes de reais ficaram nos municípios cariocas, ou seja, 67\% (sessenta e sete por cento) do total (ANP, 2011).

No que se refere à má qualidade do gasto público realizado pelas esferas subnacionais, Rodrigo Valente Serra relata que, diuturnamente, são divulgados pela mídia casos de malversação dessas receitas, tendo o autor citado algumas delas:

Algumas evidências factuais, registradas na imprensa, apontam situações preocupantes. Os prefeitos de muitas cidades beneficiárias de participações governamentais têm investido recursos públicos em finalidades exóticas como times de futebol ou em obras questionáveis. Em 23/01/2004, por exemplo, o jornal Folha de S. Paulo registrou que:

"Ajudada pelos royalties do petróleo que fez o orçamento municipal saltar de R \$ 30 milhões para R \$ 210 milhões em sete anos, a cidade [de Cabo Frio - RJ] pode se tornar uma potência no futebol brasileiro, imagina o prefeito Alair Corrêa (... [O prefeito] é apontado pelos opositores como uma versão brasileira dos príncipes árabes, 
que investem no futebol o que ganham com o petróleo (...) A prefeitura gastou $\mathrm{R} \$ 2$ milhôes só para reformar o estádio [do Cabofriense] (...) O pagamento dos atletas também segue o estilo milionário dos árabes. O salário é dado no vestiário aos jogadores. O dinheiro vem dentro de um envelope.

O caso anteriormente citado não é isolado. Vários municípios beneficiários de participações governamentais nos estados do Rio de Janeiro e Rio Grande do Norte investem em times de futebol, o que levou um ex-secretário de governo de Guamaré-RN a afirmar que "é tanto dinheiro que entra que os políticos têm que encontrar jeito de gastar”. (...) Macaé - RJ foi um pouco além, investindo não só em futebol mas também em escolas de samba. Não se pode deixar de citar, também, o caso de Rio das Ostras - RJ, que revestiu o calçadão da praia com pedras de porcelanato, material de fino acabamento e alto custo, enquanto o próprio prefeito admite que apenas $30 \% \mathrm{da}$ população tem acesso a saneamento básico (2006, p. 231-232).

Da mesma forma, Mendes e Kohler afirmam que:

Existem evidências a esse respeito na literatura. Sousa e Stosic (2003), em um estudo que compara a eficiência dos municípios brasileiros, mostram que há grande concentração de municípios que são beneficiários de royalties no grupo dos menos eficientes. Mendes (2005) mostra que os principais beneficiários de compensações financeiras relacionadas ao petróleo gastam entre $20 \%$ e $50 \%$ a mais que a média dos municípios brasileiros com a manutenção de suas câmaras de vereadores.

O que parece ocorrer é que, ainda que mal gasto, parte do dinheiro dos royalties continua circulando na área de influência econômica dos municípios beneficiados. Salários públicos elevados, despesas públicas improdutivas e desvios geram uma dinâmica econômica com baixo potencial de geração de riqueza futura, mas que é capaz de fomentar a demanda local por bens e serviços, como construção de residências, despesas no comércio, contratação de empregados domésticos, etc.

Em vez de os royalties representarem uma indenização aos municípios pela futura decadência econômica, quando não houver mais petróleo na região, eles criam uma dependência do município em relação a esses recursos no presente. Quando acabar a exploração do petróleo e os royalties secarem, esses municípios não terão construído nenhuma base sustentável para sua atividade econômica e irão, efetivamente, entrar em depressão econômica (2012, p. 3).

Diante de tais conclusões, Mendes e Kohler defendem não ser desejável a manutenção do atual modelo de distribuição dos royalties, principalmente em um contexto em que os valores se multiplicarão devido à exploração do pré-sal.

Por outro lado, afirmam também não ser aconselhável que se dividam os recursos igualmente entre todos os Estados e Municípios, uma vez que tais receitas seriam apenas "mais um recurso a ser aplicado nos gastos correntes, sem perspectiva de que venham a ser adequadamente investidos em favor das geraçóes futuras" (2012, p. 3). 
Ao final de sua análise, apresentam conselhos a ser seguidos, tendo em vista a aplicação eficaz dos royalties. O primeiro deles é o de que "a receita financeira obtida com os royalties seja investida para gerar ativos capazes de impulsionar o crescimento econômico hoje e no futuro: infraestrutura econômica, conhecimento científico, preservação ambiental" (2012, p. 3). No entanto, para a concretização de tais medidas, seria necessária uma maior concentração dos recursos no governo federal, porquanto uma parte significativa das políticas geradoras de ativos em favor das gerações futuras seriam ações típicas deste ente, competindo-lhe realizar "as principais ações de investimentos em ciência e tecnologia, proteção ambiental e ampliação da infraestrutura (estradas, portos, aeroportos etc.)" (KOHLER; MENDES, 2012, p. 3).

Por fim, os autores reconhecem que a educação é um setor cujo investimento beneficia as geraçôes futuras, com o qual Estados e Municípios poderiam contribuir significativamente. Destacam, entretanto, que seria importante que a transferência de recursos para essa finalidade previsse mecanismos que garantissem a efetiva aplicação dos recursos nas escolas públicas estaduais e municipais, apresentando como sugestão a elevação da dotação do Fundo de Desenvolvimento da Educação Básica (FUNDEB).

\subsection{REGRAS DE REPARTIÇÃO DE RECEITAS PETROLÍFERAS NO BRASIL}

\subsubsection{Um breve histórico}

Conforme exposto quando se tratou do histórico do direito de propriedade do petróleo no Brasil, a publicização das jazidas de petróleo só ocorreu após a edição do Decreto-Lei n. 366/38, que alterou o Código de Minas vigente à época (Decreto n. 24.642/34), momento em que tais recursos passaram a compor o domínio privado da União ou dos Estados, segundo a sua localização, nos termos dos artigos 96 e 97.

Em decorrência dessa alteração, determinou o artigo 108 do Decreto n. 24.642/34, também introduzido pelo Decreto-lei n. 366/38, que a União seria remunerada, à sua escolha, pela quota de $9 \%$ (nove por cento) da produção de petróleo bruto, ou pelo valor correspondente em dinheiro, a ser pago por aquele que obtivesse o direito de extrair o recurso. Quando a jazida fosse propriedade de Estado-membro, a quota seria repartida entre este e a União em partes iguais, segundo o parágrafo primeiro do mesmo artigo, devendo o ente subnacional receber sua parte sempre em dinheiro. 
Esse regime durou até a edição da Lei n. 2.004, em 3 de outubro de 1953, que instituiu no Brasil o monopólio estatal do petróleo e criou a Petróleo do Brasil S.A. - PETROBRAS.

De acordo com o artigo 27 desta Lei, a Petrobras e suas subsidiárias eram "obrigadas a pagar aos Estados e Territórios onde fizessem a lavra de petróleo, xisto betuminoso e de gás, indenização correspondente a $5 \%$ (cinco por cento) sobre o valor do óleo extraído ou do xisto ou do gás”. O parágrafo terceiro do mesmo artigo determinava que "os Estados e Territórios distribuirão 20\% (vinte por cento) do que receberem, proporcionalmente aos Municípios, segundo a produção de óleo de cada um deles, devendo este pagamento ser efetuado trimestralmente".

A Lei n. 3.257/57 alterou a alíquota devida aos Estados, diminuindo-a para $4 \%$ (quatro por cento). Porém desobrigou-os do repasse aos municípios, atribuindo a estes uma parcela própria, à razão de $1 \%$ (um por cento) da produção.

A participação de órgãos da administração pública federal nos resultados da exploração de petróleo foi inserida pela primeira vez na legislação brasileira por meio do Decreto-lei n. 523/69. Referido decreto acrescentou o parágrafo $4^{\circ}$ ao artigo 27 da Lei n. 2.004/53, determinando que a indenização de 5\% (cinco por cento) da produção, paga pelas concessionárias, deveria ser destinada, em partes iguais, ao Departamento Nacional de Produção Mineral, ao Ministério das Minas e Energia, para constituição do Fundo Nacional de Mineração, e ao Ministério da Educação e Cultura, para o incremento da pesquisa e do ensino de nível superior no campo das geociências, quando a lavra ocorresse na plataforma continental.

Com a promulgação da Constituição brasileira de 1988, o tema da partilha de receitas obtidas com a atividade petrolífera entre os entes federativos ganhou status constitucional, tendo sido imposta à União, por meio do parágrafo $1^{\circ}$ do artigo 20, a transferência de parcela dos recursos arrecadados a Estados, Municípios e Distrito Federal, em cujo território ocorresse a lavra do petróleo, bem como a órgãos da administração direta da União, nos termos do disposto em lei ordinária.

A primeira lei infraconstitucional a regular o disposto na Constituição de 1988 foi a Lei n. 7.990/89, que alterou novamente a Lei n. 2.004/53, estabelecendo em seu artigo $7^{\circ}$ mecanismos de repartição dos royalties entre os beneficiários mencionados no parágrafo $1^{\circ}$ do artigo 20 da Constituição Federal. Em seu artigo 7o, parágrafo $4^{\circ}$, atribuiu a Estados e Municípios compensação pela exploração na plataforma continental, o que não era feito até o momento.

Posteriormente, em 6 de agosto de 1997, foi editada a Lei n. 9.478/97, que em conjunto com a Lei n. 7.990/89 passou a reger a distribuição dos royalties arrecadados nos contratos de concessão, segundo os critérios analisados adiante. 
Por fim, mais recentemente, foi editada a Lei n. 12.734/2012, que modificou a Lei do Contrato de Partilha (Lei n. 12.351/2010), introduzindo os critérios de partilha dos royalties percebidos em função destes contratos.

\subsubsection{O que diz o parágrafo $1^{\circ}$ do artigo 20 da Constituição Federal?}

Como visto, a repartição das receitas petrolíferas no Estado brasileiro suscita uma série de controvérsias econômicas e políticas, as quais, conforme se passa a demonstrar, irradiam-se também no campo jurídico.

As primeiras aparecem logo no dispositivo constitucional que regulou o tema, que apesar das suas poucas linhas, é alvo de interpretaçôes absolutamente díspares.

Art. 20. São bens da Uniāo:

$\$ 1^{\circ}$ É assegurada, nos termos da lei, aos Estados, ao Distrito Federal e aos Municípios, bem como a órgãos da administração direta da União, participação no resultado da exploração de petróleo ou gás natural, de recursos hídricos para fins de geração de energia elétrica e de outros recursos minerais no respectivo território, plataforma continental, mar territorial ou zona econômica exclusiva, ou compensação financeira por essa exploração.

Tomando como foco a exploração do petróleo, o primeiro ponto a ser esclarecido diz respeito a quem são os sujeitos da relação jurídica estabelecida no excerto. Segundo a Constituição, será devida a Estados, Municípios, Distrito Federal e órgãos da administração direta uma participação no resultado da exploração de petróleo ou gás natural, ou uma compensação financeira por essa exploração. Diante disso, questiona-se: quem deverá efetuar esse pagamento? Quem são exatamente os beneficiários?

Visto isso, intenta-se conhecer o objeto da prestação devida. O que deverá ser entregue aos entes beneficiários? Toda e qualquer receita não tributária arrecadada de companhias petrolíferas? O que a Constituição quis dizer com participação no resultado ou compensação financeira pela exploração? Qual a medida da participação de cada ente? Responde-se a esses questionamentos nas linhas que se seguem.

\subsubsection{Quais são os sujeitos da relação jurídica regulada no parágrafo $1^{\circ}$ do artigo 20 da Constituição Federal?}

É comum deparar com a afirmação de que o dispositivo em epígrafe constitui-se no fundamento constitucional para o pagamento dos royalties aos entes federativos brasileiros pelas empresas contratadas para o exercício das atividades de E\&P. Neste sentido, os royalties, ao lado das participações especiais, seriam espécies de 
compensação financeira, criadas pela legislação ordinária, em obediência ao referido comando constitucional..$^{50}$

Esta questão merece ser aprofundada.

Primeiramente, deve-se ter em mente que uma coisa é a relação jurídica existente entre União e empresa petrolífera, a qual tem início a partir da assinatura de um contrato para exploração e produção de petróleo, seja de concessão ou de partilha da produção, no qual estão dispostas as obrigações a cargo de cada uma das partes. Outra, bem distinta, é o vínculo estabelecido pela lei entre a União e Estados, Municípios, Distrito Federal e órgãos da administração direta, em que o ente central tem o dever de transferir, aos beneficiários elencados pela legislação ordinária, parcela do resultado financeiro obtido com a atividade petrolífera.

Naquela primeira situação, a empresa assume uma obrigação apenas perante a União, para quem se compromete a pagar um preço, em contraprestação ao petróleo que lhe foi alienado diretamente por meio do contrato de concessão ou de partilha da produção, além de outras obrigações contratuais.

Essa relação que se estabelece entre ente público e privado se fundamenta no parágrafo $1^{\circ}$ do artigo 177 da Constituição Federal, que impõe à União a elaboração de lei com vistas a regular as condições para a contratação de empresas estatais ou privadas, para o exercício das atividades de exploração, produção, refino, importação, exportação e transporte de petróleo.

Nesse contexto, as companhias petrolíferas não possuem nenhuma responsabilidade pelo pagamento que deve ser efetuado a Estados e Municípios, a título de compensação financeira pela exploração de petróleo em seu território, conforme determina o parágrafo $1^{\circ}$ do artigo 20 , obrigação essa imposta ao ente central.

Por esse motivo, entende-se que a afirmação feita por alguns autores, de que o fundamento constitucional para o pagamento dos royalties se encontra no parágrafo $1^{\circ}$ do artigo 20, não procede, pois neste dispositivo encontra-se apenas regulada uma relação jurídica entre dois entes públicos: União, proprietária dos recursos, e ente público, beneficiário de receitas transferidas.

Não foi técnico, portanto, o legislador da Lei n. 12.351/2010 ao definir royalties como "compensação financeira devida aos Estados, ao Distrito Federal e aos Municípios, bem como a órgãos da administração direta da União, em função da produção de petróleo, de gás natural e de outros hidrocarbonetos fluidos, sob o regime de partilha de produção, nos termos do parágrafo $1^{\circ}$ do artigo 20 da Constituição

50 Neste sentido, ver Maria D’Assunção Costa (2009, p. 233). 
Federal” (art. 20, XIII). Royalties - repise-se - não são espécie de compensação financeira ou participação no resultado; estas são espécies de receita transferida, enquanto aqueles se constituem em espécie de preço público, devido em contraprestação à alienação de um bem da União.

Conclui-se, assim, que o comando contido no parágrafo $1^{\circ}$ do artigo 20 não obriga a União a cobrar royalties ou qualquer outra exação das companhias petrolíferas. Impõe somente que, do resultado financeiro obtido pela União com a venda do petróleo, uma parcela seja transferida aos beneficiários constitucionalmente eleitos, na forma que Lei Ordinária dispuser.

\subsubsection{Quem são os beneficiários eleitos pela Constituição Federal?}

Foi visto que no sistema de revenue sharing, adotado por grande parte dos países produtores de petróleo para distribuir as receitas arrecadadas com a atividade petrolífera, a escolha do beneficiário dos recursos, bem como o montante de sua participação, é definida por meio de fórmulas criadas pela legislação para essa finalidade. Tais fórmulas podem se basear em critérios mais ou menos complexos. Um exemplo bem simples é a transferência de recursos com base em critérios populacionais, por meio dos quais pode ocorrer de um ente subnacional ser beneficiado com o recebimento de receitas na mesma proporção de sua população. Outras mais complexas podem se basear em uma combinação de diversos critérios, por exemplo, população, área territorial e o inverso da participação no PIB do país.

Quando se trata de transferência de receitas petrolíferas, o critério mais comum utilizado por diversos países é o territorial, ou seja, o ente central obriga-se a transferir parte dessas receitas ao ente subnacional em cujo território sejam realizadas atividades extrativas. Contudo, tendo em vista que a utilização desse único critério leva à concentração de renda em alguns poucos entes, tem-se adotado uma combinação deste com outros que visem mitigar disparidades de renda inter-regionais.

No ordenamento jurídico brasileiro, entre todos os critérios passíveis de serem adotados para fins de repartição das receitas petrolíferas, apenas o critério territorial recebeu status constitucional. Isso se extrai da leitura do parágrafo $1^{\circ}$ do artigo 20, quando assegura a Estados, Distrito Federal e Municípios "participação no resultado da exploração de petróleo ou gás natural (...) no respectivo território". Não implica isso que outros não possam ser criados por meio de legislação ordinária, como de fato foi feito no Brasil, apenas impõe que, no mínimo, alguma parcela da receita obtida deverá ser partilhada com os Estados, Distrito Federal e Municípios onde ocorrer a extração. 
Quando a extração do recurso se dá na porção terrestre do território do ente subnacional, não há divergências interpretativas significativas sobre o conteúdo do comando expresso no parágrafo $1^{\circ}$ do artigo 20 , reconhecendo-se o direito constitucional de tais entes de ser beneficiários das receitas oriundas da atividade petrolífera desenvolvida no seu território. Por outro lado, não se verifica tal consenso quando se trata da produção do petróleo localizado na plataforma continental. Embora a legislação ordinária enquadre como beneficiários também os entes confrontantes com as áreas marítimas onde ocorre a extração, questiona-se se tal direito tem assento constitucional.

A discussão teve início por ocasião da proposição da Emenda Ibsen, que visava implementar um sistema de partilha dos royalties, percebidos por meio de contrato de concessão e de partilha da produção, por meio do qual tais recursos seriam repartidos entre todos os entes federativos brasileiros, com base nas regras do Fundo de Participação dos Estados - FPE e do Fundo de Participação dos Municípios - FPM. O autor da proposta defendia que, pelo fato de a plataforma continental, o mar territorial e a zona econômica exclusiva serem um bem da União, não seria possível falar, por exemplo, em "respectiva plataforma continental de um Estado", pois o único ente a dispor de uma "respectiva plataforma continental" seria a União. ${ }^{51}$ Desse modo, quando as atividades de exploração e produção de petróleo fossem levadas a cabo na plataforma continental, não haveria um direito constitucional dos entes confrontantes como beneficiários das receitas em questão, estando o ente central livre para, por meio de lei ordinária, decidir se os recursos seriam partilhados, bem como quais os critérios adotados.

A nosso ver, tal posicionamento parte de uma premissa equivocada: a de que Estados e Municípios brasileiros costeiros não têm, assim como a União, um território marítimo. Explica-se.

Sabe-se que a República Federativa do Brasil - representada no plano externo e interno pela União - é formada pela união indissolúvel de Estados, Municípios e Distrito Federal, todos autônomos (arts. $1^{\circ}$ e 18 da CF), possuindo cada uma dessas esferas de poder uma área territorial demarcada. $\mathrm{O}$ conjunto do território nacional é dividido em Distrito Federal e Estados, e estes, por sua vez, em Municípios, de modo que qualquer porção do território brasileiro que se aponte estará contida, ao mesmo tempo, no âmbito territorial dos três entes federativos - ou de

Posicionamento defendido em palestra proferida no 110 Encontro Internacional de Energia, promovido pela Federação das Indústrias do Estado de São Paulo - FIESP, em São Paulo/SP, no período de 9 a 10 de agosto de 2010 . 
dois, no caso do Distrito Federal. Ou seja, se uma pessoa se encontra localizada na cidade de Natal, estará, ao mesmo tempo, no território de um Município (Natal), de um Estado (Rio Grande do Norte), e da União (Brasil).

A única possibilidade de um espaço do território brasileiro fazer parte apenas da União, não estando contido ao mesmo tempo em um Estado e um Município, seria no caso de um Território Federal, ente subnacional sem autonomia político-administrativa, integrante da União (art. 18, $\$ 2^{\circ}$, da CF). Como não há atualmente no Brasil tais entes, essa situação não se verifica na prática.

Neste sentido, ainda que se trate de um bem de propriedade da União - por exemplo, as terras ocupadas pelos índios -, estará ele presente, ao mesmo tempo, no espaço territorial de um Município e de um Estado, o que evidencia, portanto, que a noção de território não se confunde com a de propriedade. Isso fica claro no tocante à porção terrestre do território brasileiro, entretanto, o mesmo não se verifica quando se trata do seu espaço marítimo.

$\mathrm{Na}$ ADIn 2.080-3/RJ discutiu-se a constitucionalidade do parágrafo $5^{\circ}$ do artigo 194 da Constituição do estado do Rio de Janeiro, ${ }^{52}$ e do parágrafo $4^{\circ}$, artigo 31 da Lei n. 2.657/96,53 do mesmo Estado. No texto de ambos reconhecia-se que a plataforma continental, o mar territorial e a zona econômica exclusiva integram o território do Estado e Município que lhes é confrontante, para fins de incidência do ICMS.

Defendendo a inconstitucionalidade dos dispositivos em questão, foram apresentados pareceres dos juristas Raul Machado Horta e Manoel Gonçalves Ferreira Filho, que se posicionaram no seguinte sentido, respectivamente:

A Constituição qualifica de bens da União os recursos naturais da plataforma continental e da zona econômica exclusiva (art. 20, V) e o mar territorial (art. 20, VI). Na sua qualificação constitucional de bens da União, a plataforma continental, o mar territorial e a zona econômica exclusiva foram colocados na competência dos poderes da Uniáo. A inclusão constitucional no campo dos poderes e da competência da União afasta qualquer intromissão dos Estados Federados e dos Municípios na área do mar territorial, da plataforma continental e da zona econômica exclusiva (...). Essa

52 Art. 194. O Estado e os Municípios poderão instituir os seguintes tributos:

(...)

$\$ 5^{\circ}$ A competência tributária do Estado e dos Municípios é exercida sobre a área dos respectivos territórios, incluídos nestes as projeções aérea e marítima de sua área continental, especialmente as correspondentes partes da plataforma continental, do mar territorial e da zona econômica exclusiva.

53 Art. 31. (...) 40 Para fins destas normas, a plataforma continental, o mar territorial e a zona econômica exclusiva integram o território do Estado e do Município que lhes é confrontante. 
matéria constitucional, introduzida na competência federal da União, impede que sobre ela possa incidir legislação municipal ou legislação estadual (grifos nossos).

O mar territorial, no direito brasileiro, está exclusivamente no domínio espacial do Poder central, ou seja, do Estado brasileiro. Não se inclui no território de qualquer Estado, nem de qualquer Município.

A Constituição não o diz expressamente, mas o demonstra claramente. Realmente, ela não deixa campo para outro Poder que não o federal, a dispor sobre o que concerne ao mar. A demonstração é fácil. Compete à União, privativamente, legislar sobre direito marítimo (art. 22, I). Compete à polícia federal exercer as funçôes de polícia marítima (art. 144, parágrafo $1^{\circ}$, III). À Justiça Federal julgar os crimes cometidos a bordo de navios (art. 109, IX). Etc.

Acrescente-se que à União é atribuída pela Carta a titularidade sobre o mar territorial. Ou seja, sobre seus recursos. Com efeito, o art. 20, VI, inclui o mar territorial entre os bens da União. (...) Evidentemente, tal plataforma se está no âmbito do Estado-nação, fica fora do alcance do Poder de qualquer dos Estados-membros, e da mesma forma além da esfera de Poder do Município (grifos nossos).

Note-se a incoerência dos argumentos apresentados. Os autores confundem institutos jurídicos que, como esclarecido, possuem diferenças conceptuais profundas, quais sejam: propriedade e território. Ao qualificar o mar territorial, a zona econômica exclusiva e a plataforma continental como bens da União, a Constituição Federal, em momento algum, considerou-os um território exclusivo da Uniāo, inserido "na competência exclusiva dos poderes da União", como afirma o Professor Raul Machado Horta; apenas assegurou ao ente central um direito de propriedade sobre aqueles.

Caso aceita a tese proposta pelos autores, segundo a qual tais espaços marítimos não se incluem "no território de qualquer Estado, nem de qualquer Município", questiona-se: seriam então um grande Território Federal? É esta a única hipótese de haver no Estado brasileiro um espaço territorial pertencente unicamente à União. Decerto que não, e por um motivo bastante evidente: a criação de um território federal, nos termos do parágrafo $2^{\circ}$ do artigo 18 da Constituição Federal, depende da edição de Lei Complementar. Como não há nenhuma Lei Complementar a instituir o "Território Federal Marítimo do Brasil”, impossível se falar na sua existência.

A eventual limitação imposta a Estados e Municípios para o exercício de suas competências nesses espaços, em virtude de estes constituírem bens da União, não implica afirmar que não integrem o seu território, cabendo-lhes legislar sobre aquilo que não for expressamente vedado pela Constituição.

Neste sentido, argumentou a Procuradoria do estado do Rio de Janeiro:

a análise da presente questão partiu de equivocada premissa: a de que o exercício das competências constitucionais dos entes políticos está relacionado com o direito 
de propriedade das áreas integrantes de seu território. Ou seja, o território de um Estado - Membro, espaço geográfico onde ele goza de autonomia e exerce as competências que lhe foram constitucionalmente atribuídas, inclusive a tributária, foi confundido com o direito de propriedade da União sobre áreas integrantes desse território. (...)

Ora, parece evidente que o fato de a Constituição atribuir a propriedade de certas áreas à União, não faz com que essas áreas deixem de estar situadas em alguma unidade da Federação. Isto porque todo o território nacional está dividido em Estados e Distrito Federal, e o território dos Estados em Municípios. Não importa quem seja o proprietário da área, geograficamente ela deve estar situada em algum Estado e Município ou no Distrito Federal (o artigo 32 da CF veda a divisão do Distrito Federal em Municípios).

Como consequência, não se pode vislumbrar, atualmente, área do território nacional sobre a qual não possam ser exercidas as competências atribuídas pela Constituição aos Estados e Municípios, ou, como disse a autora, que não possa incidir legislação municipal ou estadual (grifos nossos).

De fato, pensar em um espaço do território brasileiro, com exceção do Distrito Federal e dos Territórios Federais, que não esteja contido, ao mesmo tempo, em um Estado e um Município, seria uma violação frontal ao artigo $1^{\circ}$ da Constituição Federal. De acordo com este, "A República Federativa do Brasil é formada pela União indissolúvel dos Estados e Municípios e do Distrito Federal”. Violar-se-ia, de igual modo, o caput do artigo 18 da Lei Maior, que preconiza: "A organização político-administrativa da República Federativa do Brasil compreende a União, os Estados, o Distrito Federal e os Municípios, todos autônomos, nos termos desta Constituiçãa”.

Diante de todo o exposto, resta claro que o território de Estados e Municípios costeiros é composto, ao mesmo tempo, por uma porção terrestre e uma marítima. Desse modo, qualquer lei ordinária criada com a finalidade de regular o parágrafo $1^{\circ}$ do artigo 20 da Constituição Federal deverá, obrigatoriamente, beneficiar não só os Municípios em cujo espaço terrestre seja extraído o petróleo, mas também quando o recurso for extraído do subsolo do seu território marítimo.

\subsubsection{Por que órgãos da Administração Direta da União?}

Ao analisar a inclusão de órgãos federais como beneficiários das rendas petrolíferas, Régis Fernandes de Oliveira afirma ser "sem sentido que assim se estabeleça, uma vez que órgãos da União não podem receber recursos diretamente". $\mathrm{O}$ autor prossegue em sua explicação aduzindo que "o legislador constituinte não é técnico e, pois, utiliza palavras em desconexão jurídica. Ora, nenhuma vinculação é permitida nos exatos termos do inciso IV do art. $167 \mathrm{da} \mathrm{CF}$, preservadas as exceçôes referidas" (2008, p. 229, grifos nossos). 
Da mesma forma, Kiyoshi Harada entende ser "estranho que a Constituição tenha incluído como beneficiários da compensação financeira os órgãos federais, que não têm personalidade jurídica própria como a União, que é titular dos recursos naturais da plataforma continental" (2009, p. 81).

A despeito de tais posicionamentos, entende-se que o dispositivo apenas reforça a possibilidade de a União vincular parte da receita obtida com a venda do petróleo a órgãos da administração federal. Isso poderia ser feito por meio de Lei Ordinária, ainda que a Constituição silenciasse sobre o assunto, pois a regra contida no inciso IV do artigo 167 da Constituição Federal, citada por Regis de Oliveira, apenas veda a vinculação de impostos, não das receitas públicas em geral. Neste sentido, posiciona-se André Castro Carvalho ao analisar o regime jurídico das vinculações:

No Brasil, por outro lado, a não afetação apareceu explícita na Constituição e restrita a uma espécie tributária (imposto), reforçando o comando no que concerne a este tributo e enfraquecendo-o no tocante às demais espécies tributárias e outras receitas não tributárias, permitindo-se a plena vinculação delas por leis ordinárias (2010, p. 175).

Assim, tem-se que o parágrafo $1^{\circ}$ do artigo 20 constitui uma norma jurídica de caráter permissivo, pois atribui ao legislador ordinário uma permissão no sentido de vincular ou não parte desse tipo de receita a órgãos da administração direta, diferentemente do que ocorre com relação a Estados e Municípios, em que a União está obrigada a transferir-lhes parte da receita obtida com a venda do petróleo, segundo critérios territoriais.

Ao vincular aos Ministérios da Marinha, Minas e Energia, Ciência e Tecnologia e Meio Ambiente parcela desses recursos, privilegiou-se a sua aplicação em áreas que de alguma forma têm por objetivo dar suporte à atividade petrolífera, ou mesmo combater efeitos nocivos por ela causados. De todo modo, é uma decisão política que pode variar com o tempo e com a importância do setor na economia.

Vale destacar, por fim, que apesar de a lei estipular uma porcentagem de recursos a ser destinada a tais órgãos, na prática vale o disposto na Lei Orçamentária. Tanto é assim que os parágrafos $2^{\circ}$ e $3^{\circ}$ do artigo 45 da Lei n. 9.478/97 assim determinaram:

$\$ 2^{\circ}$ As receitas provenientes das participações governamentais definidas no caput, alocadas para órgãos da administração pública federal, de acordo com o disposto nesta Lei, serão mantidas na Conta Única do Governo Federal, enquanto não forem destinadas para as respectivas programações.

$\$ 3^{\circ} \mathrm{O}$ superávit financeiro dos órgãos da administração pública federal referidos no parágrafo anterior, apurado em balanço de cada exercício financeiro, será transferido ao Tesouro Nacional (grifos nossos). 
Com isso, será destinado especificamente para os Ministérios beneficiários somente aquilo que for aprovado na Lei Orçamentária Anual, sendo o superávit financeiro transferido ao Tesouro Nacional.

\subsubsection{Qual a diferença entre compensação e participação?}

A utilização pelo constituinte originário das expressões participação e compensação financeira causa certa divergência na doutrina, no que tange ao conceito dos referidos institutos.

Aurélio Pitanga Seixas Filho (1998, p. 32) entende que não há diferença entre um e outro regime jurídico, posicionando-se nos seguintes termos:

Não me parece, também, existir uma distinção de regime jurídico entre a remuneração devida pela participação na exploração do recurso mineral e a compensação financeira, pois a diferença entre as duas hipóteses restringir-se-ia, unicamente, à maneira de calcular ou dimensionar a remuneração devida pela utilização do recurso mineral pertencente à União Federal.

No mesmo sentido, Régis Fernandes de Oliveira afirma que:

Ambos quiseram referir-se à mesma coisa, ou seja, quando houver a exploração mineral ou de energia elétrica, dos resultados financeiros daí advindos haverá a divisão (partilha ou compensação) entre os entes federados. Não haveria como disciplinar nova partilha, por outra lei, de forma a ensejar participação, uma vez que a Lei n. 7.990/89 fala em compensação, mas dispõe sobre partilha (2008, p. 227-228).

No campo daqueles que enxergam uma diferenciação entre os institutos, afirma Ricardo Lobo Torres:

Podem a União, os Estados e os Municípios receber participação representada pelas importâncias calculadas sobre o resultado da exploração de petróleo ou gás natural etc., matéria ainda não regulamentada.

Ou podem receber compensaçōes financeiras, que têm a natureza de preços públicos pela utilização de recursos naturais situados em seus territórios (2007, p. 191).

Também para Manoel Gonçalves Ferreira Filho, representam realidades jurídicas distintas, pois "a norma distingue entre participação e compensação. Esta última pressupõe um prejuízo decorrente da exploração. Já a participação constitui uma associação de benefícios" (1992, p. 154).

No julgamento do Recurso Extraordinário 288.800, o então Ministro do Supremo Tribunal Federal, Sepúlveda Pertence, diferenciou em seu voto a participação nos resultados da compensação financeira, referindo-se à CFEM minerária nos seguintes termos: 
$\mathrm{Na}$ verdade - na alternativa que lhe confiara a Lei Fundamental = o que a Lei $\mathbf{n}$. 7.990/89 instituiu, ao estabelecer no art. $6^{\circ}$ que "a compensação financeira pela exploração de recursos minerais, para fins de aproveitamento econômico, será de até $3 \%$ sobre o valor do faturamento líquido resultante da venda do produto mineral", não foi verdadeira compensação financeira: foi, sim, genuína "participação no resultado da exploração", entendido o resultado não como o lucro do explorador, mas como aquilo que resulta da exploração, interpretação que revela o paralelo existente entre a norma do art. $20, \$ 1^{\circ}$, e a do art. $176, \S 2^{\circ}$, da Constituição, in verbis: $\$ 2^{\circ}$ É assegurada participação ao proprietário do solo nos resultados da lavra, na forma e no valor que dispuser a lei.

Ora, tendo a obrigação prevista no art. $6^{\circ}$ da Lei 7.990/89 a natureza de participação no resultado da exploração, nada mais coerente do que consistir o seu montante numa fração do faturamento.

Nada importa que - tendo-a instituído como verdadeira "participação nos resultados" da exploração mineral, a lei lhe haja emprestado a denominação de “compensação financeira” pela mesma exploração - outro termo da alternativa posta pelo art. $20, \$ 1^{\circ}$, da Constituição: cuidando-se de obrigação legal, de fonte constitucional, ainda que não seja tributo, é dado transplantar, mutatis mutandis para identificar a natureza da CFEM, a regra de hermenêutica do art. 4º, I, CTN, que adverte da irrelevância da denominação dada à exação.

A primeira consequência que se pode extrair do referido julgado é o reconhecimento, pela Suprema Corte, de que participação no resultado e compensação financeira são institutos distintos. Em segundo lugar, tem-se que a participação no resultado da exploração e a compensação financeira são formas de remuneração. Aquela é devida simplesmente com base em uma fração do preço auferido pela União com a venda do petróleo, enquanto esta seria quantificada com base no valor de um "dano" sofrido pelo ente subnacional, em virtude da realização de atividades extrativas em seu território. Por último, entendeu-se que o legislador ordinário estaria livre para adotar um ou outro modelo de remuneração.

Trata-se de institutos completamente diversos. A compensação financeira, em virtude do seu caráter indenizatório, deve necessariamente conter um limite em relação ao quantum devido, o qual corresponde aos danos causados aos entes subnacionais. Já a participação no resultado da exploração consiste, segundo Manoel Gonçalves Ferreira Filho, "em uma associação de benefícios".

Dessa forma, como bem exposto no voto citado, embora a Lei por diversas vezes utilize a expressão "compensação financeira”, em verdade, tem-se no Brasil apenas o modelo de participação nos resultados. Tanto é assim que toda a transferência de receita feita aos beneficiários eleitos pela legislação se dá com base em uma porcentagem do faturamento obtido pela União com a venda do petróleo, não havendo, em nenhuma hipótese - atualmente - limitação do valor recebido. 


\subsubsection{Parcelas de todas as receitas arrecadadas com a atividade petrolífera devem ser repartidas?}

É possível extrair do parágrafo $1^{\circ}$ do artigo 20 da Constituição determinação segundo a qual todo e qualquer valor (não tributário) obtido pela União a título de participação governamental com a atividade petrolífera deve ser repartido com Estados e Municípios? A resposta ao questionamento proposto mostra-se de fundamental importância para que se compreenda quais espécies de participações governamentais a Constituição impõe que sejam partilhadas com tais entes. Fabricio Rozario Valle Dantas Leite, para quem a expressão compensação financeira, aposta no parágrafo $1^{\circ}$ do artigo 20 da CF, é sinônimo de participação governamental, entende que todo tipo de receita auferida pela União com a atividade petrolífera deve ser partilhada, inclusive bônus de assinatura e pagamento pela ocupação ou retenção de área. Defende que:

Como o bônus de assinatura se insere no gênero legal das participações governamentais que, por sua vez, é parte do conceito constitucional de compensação financeira pela exploração dos recursos minerais, os valores excedentes desta receita, ou seja, aqueles que forem superiores ao valor mínimo fixado em edital e que, ademais, sejam superiores às necessidades orçamentárias da ANP, deverão ser repartidos, na forma prevista no parágrafo $1^{\circ}$ do artigo 20 da Constituição. (...)

O pagamento pela ocupação ou retenção da área, segundo dispõe o artigo 51 da Lei n. 9.478/97, é realizado anualmente e tem o valor fixado por quilômetro quadrado ou por fração da superfície do bloco, no edital e no contrato.

Mais uma vez, como ocorre com o bônus de assinatura, não há previsão de critério legal para a repartição do resultado da arrecadação com todas as unidades da federação, em clara violação ao parágrafo $1^{\circ}$ do artigo 20 da Constituição. Pelo contrário, o artigo 16 da Lei n. 9.478/97, prevê que os recursos arrecadados com esta participação governamental serão exclusivamente utilizados para o financiamento das despesas da ANP no exercício de suas atividades, desconsiderando a imposição constitucional de repartição com os demais entes (2009, p. 531-533).

Este não parece ser o entendimento mais acertado, pois, caso se analise de maneira mais detida o texto constitucional, verificar-se-á haver determinação apenas para que se assegure a Estados e Municípios participação no resultado da exploração de petróleo e gás - ou compensação financeira por essa exploração - auferido pela União. Ora, o resultado contratado pelo ente central por meio de contrato de exploração e produção petrolífera, conforme demonstrado linhas anteriormente, é a extração do petróleo, e sua entrega in natura ou convertido em pecúnia, de modo que somente as participaçóes governamentais que representem espécie de receita pública proveniente desse resultado é que devem ser partilhadas. Quer-se dizer que 
a obrigatoriedade constitucional de transferir a Estados e Municípios parcela das receitas arrecadadas com a atividade petrolífera deverá recair, nos termos em que a lei determinar, sobre aquelas auferidas com a venda do petróleo, seja por meio de negócio jurídico de compra e venda inserto no contrato petrolífero, seja em decorrência da receita obtida com a venda do petróleo recebido in natura.

Visto isso, deve-se indagar também se toda a receita auferida pela União com a venda do petróleo deve ser repartida. Ou seja: qual é a base de cálculo a ser utilizada para o cálculo da transferência das receitas petrolíferas a Estados e Municípios em cujo território se localizam atividades extrativas? Segundo parece, a Constituição é clara ao determinar que a base de cálculo para as transferências será o resultado da exploração, isto é, todo o resultado financeiro obtido pela União com a venda do petróleo, seja diretamente com a companhia de E\&P, seja por meio de contrato de compra e venda firmado posteriormente com outra empresa. Consequentemente, de maneira diversa do que consta atualmente nas Leis ns. 12.351/2010 e 12.276/2010, também a receita obtida com a venda do petróleo percebido in natura pela União serviria de base para o cálculo das transferências, bem como aquela auferida pelo ente central com a venda do petróleo que se encontra ainda na forma de depósito na plataforma continental, por meio do contrato de cessão onerosa.

Questão semelhante encontra-se atualmente em discussão na Ação Direta de Inconstitucionalidade n. 4492, interposta pelo Governador do estado do Rio de Janeiro perante o Supremo Tribunal Federal, por meio da qual se insurge contra a ausência de previsão, na lei que instituiu o Contrato de Cessão Onerosa (Lei n. 12.276/2010), da cobrança de participaçôes especiais nos blocos ali cedidos, e a consequente ausência da transferência de parcela desses valores ao estado do Rio de Janeiro e respectivos Municípios.

Defende-se que a Lei n. 9.478/97 teria caráter geral com relação à Lei n. 12.276/2010. Assim, ao prever expressamente em seu artigo $5^{\circ}$ apenas o pagamento de royalties, esta norma não teria afastado "a incidência de qualquer outra espécie de compensação financeira devida aos Estados e Municípios produtores, como a chamada participação especial”, prevista na Lei n. 9.478/97. Neste sentido, o estado do Rio de Janeiro aduz em sua petição inicial que:

A Lei n. 12.276 assume, nitidamente, a feição de Lex specialis, que não derroga as disposições da lei geral senão naquilo que tenha sido expressamente tratado de modo diverso.

A chamada cessão onerosa resta plenamente aplicável a Lei n. 9.478 em tudo que não tenha sido objeto de disposição legal em contrário. É exatamente o caso da participação especial, elemento de concretização do direito constitucional à plena compensação 
financeira (art. 20, parágrafo $1^{\circ}$ ), cuja incidência não restou expressamente afastada pela Lei n. 12.276.

Entende-se que a questão foi mal colocada pelo estado do Rio de Janeiro. Primeiramente, deve-se ter em mente que não há nenhum dispositivo constitucional que imponha à União o dever de adotar esta ou aquela forma de obter o resultado com a venda do petróleo do qual é titular. Pode optar por receber todo o resultado contratado diretamente em petróleo, ou convertido em pecúnia, por meio de uma ou mais espécie de royalties. O fato de a Lei n. 12.276/2010 ter previsto o pagamento de apenas uma espécie de royalty lato sensu é uma decisão política atribuída pela Constituição Federal à União, que foi taxativa ao impor apenas o royalty do contrato de cessão onerosa (RCCO). Portanto, não há que se falar na aplicação do disposto em lei geral - caso se atribua natureza de lei geral à Lei n. 9.478/97 -, quando a lei específica esgotou o tratamento da matéria.

Argumentou a União em sua contestação que não se pode extrair do artigo 20, parágrafo $1^{\circ}$, da Constituição "o direito dos entes federados à percepção da participação especial, já que essa norma constitucional não especifica o tipo de participação ou compensação que lhes é devida, atribuindo essa escolha à discricionariedade do legislador ordinário".

Por outro lado - e daí se entender que o estado do Rio de Janeiro colocou a questão de maneira equivocada -, a União deixou de transferir a Estados e Municípios parcela dos 74.808 bilhões de reais recebidos da Petrobras por meio do Contrato de Cessão Onerosa. Estes, somados aos futuros royalties, correspondem ao preço total pago pelo petróleo negociado entre as partes por meio desse contrato. Com isso, tem-se que ao tomar para si toda a receita paga pela Petrobras no ato de assinatura do contrato de cessão onerosa, a União deixou de observar o comando constitucional do parágrafo $1^{\circ}$ do artigo 20, que reserva aos entes subnacionais produtores participação no resultado da venda do petróleo.

No entanto, a concentração de maior parte do produto da venda do petróleo nos entes subnacionais tende a gerar uma maior ineficiência do gasto público, como apontado pela doutrina econômica na primeira seção deste capítulo. Uma solução mais adequada seria a participação de Estados e Municípios com alíquotas menores do que as adotadas atualmente.

\subsubsection{Há um quantum mínimo ou máximo?}

Suponha que a União editasse lei estabelecendo as seguintes alíquotas para a distribuição da participação no resultado da exploração: União (98\%), Estados produtores (1\%) e Municípios produtores (1\%). Diante desta situação, pergunta-se: seria 
constitucional essa norma? Responde-se: depende. E se, por outro lado, fosse estabelecido que caberia à União apenas $2 \%$ da produção, enquanto Estados e Municípios produtores ficariam com $49 \%$ cada, estar-se-ia diante de uma norma constitucional? Mais uma vez seria o caso de se responder: depende.

A nosso ver, a Constituição tão só estabelece qual deve ser a base de cálculo da participação sobre o resultado a ser transferida. A medida desta participação, a ser dosada por meio das alíquotas incidentes, foi deixada para ser estabelecida pela legislação ordinária.

Costuma-se dizer que a parcela dos royalties transferida a Estados e Municípios teria uma natureza indenizatória, pois se destinaria a compensar tais entes pelos danos causados pela atividade exploratória em seu território. Até mesmo o Manual de Contabilidade Aplicado ao Setor Público (2012), ao definir compensações financeiras (leia-se, participações no resultado), aduz que "elas têm como finalidade recompor financeiramente os prejuízos ou danos causados (externalidades negativas) pela atividade econômica na exploração desses bens, assim como proporcionar meio de remunerar o Estado pelos ganhos obtidos por essa atividade”.

A nosso ver, a teoria indenizatória faz sentido apenas como critério de razoabilidade para aferir o montante a ser repassado a Estados e Municípios em cujo território ocorrem atividades extrativas, que deve ser compatível com os gastos extraordinários suportados por estes em razão da produção de petróleo.

Certamente, um Município confrontante, localizado a milhas de distância das operações de extração, sofrerá um impacto significativamente menor do que quando esta atividade se localiza em terra. Além disso, pode ocorrer de um Município confrontante não ser o mais afetado em caso de vazamento de óleo, devido à existência de correntes marítimas na região, ou mesmo porque as operações de embarque e desembarque estão localizadas em outro Município, gerando para este um maior gasto devido ao aumento populacional e a necessidade de ampliação da infraestrutura e serviços públicos locais. Todas essas questôes devem ser levadas em consideração na fixação das alíquotas; até mesmo a evolução da arrecadação tributária do ente - que por si só já seria uma forma de compensar o aumento dos gastos.

Desse modo, tem-se que a resposta aos questionamentos propostos no início deste item deve ser obtida à luz do princípio da razoabilidade. Tal princípio deve servir, portanto, ao Legislativo, como parâmetro para o estabelecimento das alíquotas das receitas petrolíferas a serem transferidas, e ao Judiciário, para a sua revisão, caso as alíquotas estabelecidas pela legislação não sejam razoáveis - seja por não compensarem devidamente os entes subnacionais, seja por destinarem a estes um montante muito superior ao adequado, em detrimento de toda a federação, que 
deixa de se beneficiar com os recursos provenientes de um bem que pertence à União e que, a priori, deveria beneficiar a todos igualmente.

\subsubsection{Critérios de repartição especificados na legislação ordinária}

Desde a descoberta da camada pré-sal em 2009, e do seu potencial em termos de geração de receita pública para o Estado brasileiro, deu-se início a um acirrado debate no meio político entre representantes dos Estados e Municípios em cujo território ou plataforma continental adjacente se localizam atividades extrativas, e os demais entes da federação.

Os entes chamados de "produtores" defendiam a manutenção das regras instituídas pelas Leis ns. 9.478/97 e 7.990/89, que lhes beneficiava com um aporte de receitas petrolíferas visto como excessivo pelos demais Estados e Municípios. Estes, por não possuírem atividades extrativas em seu território, não se beneficiavam com transferências desses recursos, os quais, do seu ponto de vista, deveriam aproveitar a todos, por decorrerem de um bem cujo titular é a União Federal.

Nesse contexto, foi proposto no Congresso Nacional o Projeto de Lei n. 5.938/2009. ${ }^{54}$ A versão apresentada para sanção presidencial continha dispositivo (introduzido pela Emenda n. 387, feita em coautoria pelos Deputados Federais Humberto Souto e Ibsen Pinheiro) segundo o qual a parcela dos royalties e participações especiais, arrecadada pelo governo federal por meio de contrato de partilha ou de concessão, a ser transferida para Estados e Município, deveria ser repartida entre todos os entes da federação, de acordo com os critérios do Fundo de Participação dos Estados (FPE) ${ }^{55}$ e do Fundo de Participação dos Municípios (FPM). ${ }^{56}$ Tal dis-

54 Posteriormente convertido na Lei n. 12.351, de 22 de dezembro de 2010.

55 A partilha dos recursos do FPE segue a seguinte lógica:

(i) Da receita arrecadada pela União com o Imposto de Renda (IR) e com o Imposto sobre Produtos Industrializados (IPI), 21,5\% devem ser destinados ao Fundo de Participação dos Estados, com base nos seguintes critérios:

(ii) $85 \%$ da receita desse fundo é destinada aos Estados das Regiōes Norte, Nordeste e Centro-Oeste, o restante para o Sul e Sudeste.

(iii) Após esta primeira repartição, o restante é dividido entre os Estados da seguinte forma: $5 \%$ pela extensão territorial

95\% com base no produto entre o coeficiente representativo da população pelo inverso da renda per capita.

(iv) Tais critérios, embora tenham atualmente sua constitucionalidade questionada perante o STF, continuam vigentes até a presente data (28.01.2013).

56 A partilha dos recursos do FPM ocorre da seguinte forma:

(i) $22,5 \%$ das receitas arrecadadas com o IR e do IPI são destinadas aos Municípios de acordo com os seguintes critérios: 
positivo foi alvo de severas críticas por parte dos entes produtores, não só por defenderem a continuidade das regras até então vigentes, mas principalmente pelo fato de o Projeto de Lei em comento alterar inclusive as áreas já licitadas anteriormente.

No entanto, a parte do Projeto de Lei que visava introduzir esse novo sistema de partilha foi vetada pelo Presidente Lula, tendo a questão sido objeto de nova proposição legislativa (Projeto de Lei do Senado n. 448/2011). Esta, em 30 de novembro de 2012, transformou-se na Lei n. 12.734/2012, por meio da qual foram instituídas novas regras de distribuição dos royalties para os contratos de partilha e de concessão.

A Lei n. 12.734/2012, por sua vez, também teve diversos dispositivos vetados pelo Presidente da República sobre o tema da partilha, vetos esses que foram posteriormente derrubados pelo Congresso Nacional em 14 de março de 2013.

Contudo, o governador do Estado do Rio de Janeiro ajuizou a Ação Direta de Inconstitucionalidade n. 4.917, perante o Supremo Tribunal Federal, em face da versão final aprovada pelo Congresso Nacional, medida esta que restou provida em sede de decisão liminar proferida pela Ministra Cármen Lúcia, em 18 de março de 2013.

Sendo assim, as regras de partilha analisadas a seguir serão aquelas publicadas por meio da Lei n. 12.734/2012, em 30 de novembro de 2012, que alteraram as Leis ns. 9.478/97 e 12.351/2010, mas que não estão com sua eficácia suspensa por meio da referida Ação Direta de Inconstitucionalidade.

Desse modo, existem em vigor no Brasil, atualmente, três sistemas de partilha das receitas petrolíferas, regidos por três diplomas legais distintos: Lei n. 7.990/89, Lei n. 9.478/97 e Lei n. 12.351/2010. As duas primeiras regem a repartição dos royalties lato sensu (RCC, PE e RCCO), apurados por meio dos contratos de concessão e de cessão onerosa, enquanto a última se destina a regular a distribuição dos royalties apurados nos contratos de partilha da produção (RCP). São eles:

(ii) Deste montante, há uma primeira divisão, na qual 10\% dos valores do fundo são destinados aos Municípios da capital, enquanto $90 \%$ dos recursos são destinados aos municípios do interior.

(iii) Feito isso, os recursos repassados aos municípios das capitais são distribuídos com base em coeficientes obtidos com base em critérios populacionais, isto é, quanto maior a população maior a participação, e o inverso da renda per capita.

(iv) Já com relação aos Municípios do interior, 96\% dessas receitas serão distribuídas com base apenas na população do Município. Os outros $4 \%$ serão distribuídos entre os municípios com mais de 156 mil habitantes, com base na população e no inverso da renda per capita. 
(i) sistema de distribuição dos royalties dos contratos de concessão e de cessão onerosa, ${ }^{57}$ aplicável aos contratos com produção desenvolvida nos campos (i.1) onshore e (i.2) offshore, , $^{58}$

(ii) sistema de distribuição das participações especiais auferidas nos contratos de concessão;

(iii) sistema de distribuição dos royalties auferidos nos contratos de partilha da produção, (v.1) onshore e (v.2) offshore.

Para uma melhor compreensão do tema, sumarizam-se tais sistemas nas tabelas a seguir:

Tabela 6.1 Repartição dos RCCs - Produção onshore - Contratos de Concessão

\begin{tabular}{|l|c|c|}
\hline \multicolumn{1}{|c|}{ BENEFICIÁRIOS } & $\begin{array}{c}\text { DISTRIBUIÇÃO DA ALÍQUOTA } \\
\text { DE 5\% (LEI N. 7.990/89 } \\
\text { E DECRETO N. 1/91) }\end{array}$ & $\begin{array}{c}\text { DISTRIBUIÇÃO DA ALíQUOTA } \\
\text { EXCEDENTE A 5\% } \\
\text { (LEI N. 9.478/97 } \\
\text { E DECRETO N. 2.705/98) }\end{array}$ \\
\hline Estados produtores & $70,0 \%$ & $52,5 \%$ \\
\hline Municípios produtores & $20,0 \%$ & $15,0 \%$ \\
\hline $\begin{array}{l}\text { Municípios com instalações de } \\
\text { embarque e desembarque de } \\
\text { petróleo e gás natural }\end{array}$ & $10,0 \%$ & - \\
\hline $\begin{array}{l}\text { Municípios afetados por } \\
\text { operações de embarque e } \\
\text { desembarque de petróleo } \\
\text { e gás natural }\end{array}$ & - & $7,5 \%$ \\
\hline Fundo Social & - & $25,0 \%$ \\
\hline Total & $\mathbf{1 0 0 , 0 0} \%$ & $\mathbf{1 0 0 , 0 0} \%$ \\
\hline
\end{tabular}

Fonte: elaborado pela autora.

57 Todas as áreas abarcadas pelo contrato de cessão onerosa referem-se à extração de petróleo offshore.

58 Especificamente com relação aos royalties e participaçôes especiais auferidos mediante contratos de concessão, cuja declaração de comercialidade tenha ocorrido antes de 3 de dezembro de 2012, quando oriundos da produção realizada no horizonte geológico denominado pré-sal, receberão a seguinte destinação de acordo com o art. 3o da Lei n. 12.858/2013: "Art. 3o Os recursos dos royalties e da participação especial destinados à União, provenientes de campos sob o regime de concessão, de que trata a Lei n 9.478, de 6 de agosto de 1997, cuja declaração de comercialidade tenha ocorrido antes de 3 de dezembro de 2012, quando oriundos da produção realizada no horizonte geológico denominado pré-sal, localizados na área definida no inciso IV do caput do art. $2^{\circ}$ da Lei n 12.351, de 22 de dezembro de 2010, serão integralmente destinados ao Fundo Social previsto no art. 47 da Lei n. 12.351, de 22 de dezembro de 2010". 
Tabela 6.2 Repartição dos RCCs e RCCOs - Produção offshore

\begin{tabular}{|l|c|c|}
\hline \multicolumn{1}{|c|}{ BENEFICIÁRIOS } & $\begin{array}{c}\text { DISTRIBUIÇÃO DA ALÍQUOTA } \\
\text { DE 5\% } \\
\text { (LEI N. 7.990/89 } \\
\text { E DECRETO N. 1/91) }\end{array}$ & $\begin{array}{c}\text { DISTRIBUIÇÃO DA ALÍQUOTA } \\
\text { EXCEDENTE A 5\% } \\
\text { (LEI N. 9.478/97 } \\
\text { E DECRETO N. 2.705/98) }\end{array}$ \\
\hline Estados confrontantes & $30,0 \%$ & $22,5 \%$ \\
\hline $\begin{array}{l}\text { Municípios confrontantes e suas } \\
\text { respectivas áreas geoeconômicas }\end{array}$ & $30,0 \%$ & $22,5 \%$ \\
\hline $\begin{array}{l}\text { Municípios onde se localizam } \\
\text { instalações de embarque e } \\
\text { desembarque de petróleo }\end{array}$ & $10,0 \%$ & - \\
\hline $\begin{array}{l}\text { Municípios afetados por } \\
\text { operações de embarque e } \\
\text { desembarque de petróleo }\end{array}$ & - & $7,5 \%$ \\
\hline Ministério (Comando) da Marinha & $20,0 \%$ & $15,0 \%$ \\
\hline Ministério da Ciência e Tecnologia & - & $25,0 \%$ \\
\hline Fundo especial & $10,0 \%$ & $7,5 \%$ \\
\hline Total & $\mathbf{1 0 0 , 0 0} \%$ & $\mathbf{1 0 0 , 0 0} \%$ \\
\hline
\end{tabular}

Fonte: elaborado pela autora.

Tabela 6.3 Repartição das Participações Especiais - Produção onshore

\section{ou offshore}

\begin{tabular}{|l|c|}
\hline \multicolumn{1}{|c|}{ BENEFICIÁRIO } & ALÍQUOTA \\
\hline Estados ou o Distrito Federal & $40 \%$ \\
\hline Municípios & $10 \%$ \\
\hline Ministério de Minas e Energia & $40 \%$ \\
\hline Ministério do Meio Ambiente & $10 \%$ \\
\hline
\end{tabular}

Fonte: elaborado pela autora.

Tabela 6.4 Repartição dos RCPs - Produção onshore

\begin{tabular}{|l|c|}
\hline \multicolumn{1}{|c|}{ BENEFICIÁRIO } & ALíQUOTA \\
\hline Estados ou o Distrito Federal & $20 \%$ \\
\hline Municípios & $10 \%$ \\
\hline $\begin{array}{l}\text { Municípios afetados por operações de embarque } \\
\text { e desembarque de petróleo, gás natural e outro } \\
\text { hidrocarboneto fluido }\end{array}$ & $5 \%$ \\
\hline
\end{tabular}




\begin{tabular}{|l|c|}
\hline $\begin{array}{l}\text { Fundo Especial para Estados e Distrito Federal } \\
\text { (critérios FPE) }\end{array}$ & $25 \%$ \\
\hline Fundo especial para municípios (critérios FPM) & $25 \%$ \\
\hline $\begin{array}{l}\text { União, a ser destinado ao Fundo Social, instituído } \\
\text { por esta Lei, deduzidas as parcelas destinadas } \\
\text { aos órgãos específicos da Administração Direta } \\
\text { da União, nos termos do regulamento do Poder } \\
\text { Executivo }\end{array}$ & $15 \%$ \\
\hline
\end{tabular}

Fonte: elaborado pela autora.

Tabela 6.5 Repartição dos RCPs - Produção offshore

\begin{tabular}{|l|c|}
\hline \multicolumn{1}{|c|}{ BENEFICIÁRIO } & ALÍQUOTA \\
\hline Estados confrontantes & $22 \%$ \\
\hline Municípios confrontantes & $5 \%$ \\
\hline $\begin{array}{l}\text { Municípios afetados por operações de embarque e desembarque } \\
\text { de petróleo, gás natural e outro hidrocarboneto fluido }\end{array}$ & $2 \%$ \\
\hline Fundo Especial para Estados e Distrito Federal (critérios FPE) & $24,5 \%$ \\
\hline Fundo especial para municípios (critérios FPM) & $22 \%$ \\
\hline União (Fundo Social) & \\
\hline
\end{tabular}

Fonte: elaborado pela autora.

Algumas conclusões podem ser formuladas a partir da análise das tabelas. Primeiramente, verifica-se que, exceto com relação às participações especiais, os beneficiários e os critérios de repartição dos royalties diferem em virtude de a produção ocorrer em terra, lagos, rios, ilhas fluviais ou lacustres (onshore), ou na plataforma continental (offshore), assegurando-se sempre uma participação maior aos entes subnacionais caso a produção ocorra em terra, do que quando for desenvolvida na plataforma continental marítima, devido aos maiores impactos, potenciais ou efetivos, que sofrem em seu território.

Durante os debates que ocorreram no Congresso para a alteração dos critérios de partilha dos royalties dos contratos de concessão, pôde-se perceber que havia um sentimento, de certa forma pacífico, de que era justo que Estados e Municípios afetados no espaço terrestre do seu território (onshore) continuassem a receber as mesmas porcentagens estabelecidas na legislação até então vigente, o que de fato ocorreu, de modo que as regras de repartição para esses entes permaneceram inalteradas. 
Por outro lado, embora tenha havido um movimento pela redução da participação dos Estados e Municípios confrontantes (offshore) na partilha das receitas petrolíferas, e a consequente ampliação dos demais entes da federação, por meio da elevação das porcentagens destinadas aos Fundos Especiais dos Estados e dos $\mathrm{Mu}-$ nicípios, ${ }^{59}$ tal intuito não chegou a se concretizar até o momento. Ocorre que, conforme mencionado acima, a Lei n. 12.734/2012, com a redação final que lhe foi dada pelo Congresso Nacional após a derrubada dos vetos presidenciais, encontra-se com seus efeitos suspensos em virtude de decisão liminar do Supremo Tribunal Federal, proferida em 18 de março de 2013, pela Ministra Cármem Lúcia, na ADIN n. 4.917, beneficiando dessa maneira os Estados e Municípios confrontantes.

De acordo com os dispositivos suspensos, tais fundos especiais, que no regime anterior eram compostos apenas por uma média de 8,75\% dos RCCs auferidos na produção offshore, passariam a contar com $42 \%$ dos RCCs (produção offshore) em 2013. Esta participação aumentaria gradualmente para 54\% a partir de 2020; $20 \%$ das participaçóes especiais em 2013, também com aumento gradual até 30\% em 2020; além de 50\% dos RCPs quando a produção for onshore, e 49\% no caso de atividades offshore.

Essa ampliação da participação do restante da federação representaria um avanço caso se considere o objetivo constitucional de reduzir as desigualdades regionais no país, contudo, isso não implica que essa nova forma de distribuição propiciará uma aplicação mais eficiente desses recursos. Para tanto, fazem-se necessários mecanismos que restrinjam sua utilização em despesas com o custeio da máquina pública, como bem ponderou Marcos Mendes, ao demonstrar preocupação de que, com a distribuição igualitária dessas receitas, tenha-se apenas "mais um recurso a ser aplicado nos gastos correntes, sem perspectiva de que venham a ser adequadamente investidos em favor das geraçōes futuras" (2012, p. 3).

Outra novidade criada por meio da Lei n. 12.351/2010 diz respeito à instituição do Fundo Social, a ser composto pelas seguintes receitas: royalties destinados à União por meio dos contratos de concessão e cessão onerosa; RCPs; e toda a receita auferida pela União com a venda da sua parte em óleo, obtida no contrato de partilha. No entanto, deixou-se de estabelecer na lei como essa destinação será compatibilizada com a necessidade de a União transferir as porcentagens estabele-

Consistem em espécies de fundo público de destinação, criados pela União, por meio dos quais se transfere a Estados (via Fundo Especial dos Estados) e aos Municípios (via Fundo Especial dos Municípios), parcela dos royalties arrecadados com a venda do petróleo, com base nos critérios do FPE e FPM, respectivamente. 
cidas na Lei n. 9.478/97 para seus órgãos, tais como Ministério de Ciência e Tecnologia, Ministério de Meio Ambiente, Ministério de Minas e Energia e Marinha do Brasil. Provavelmente, a questão será resolvida da maneira como tem sido feito atualmente, explicada no item 6.4.2.3, em que as porcentagens a ser transferidas aos órgãos da Administração Federal são ajustadas na Lei Orçamentária da União.

Por definição legal, trata-se de um fundo de natureza contábil e financeira, vinculado à Presidência da República, com a finalidade de constituir fonte de recursos para o desenvolvimento social e regional, na forma de programas e projetos nas áreas de combate à pobreza e de desenvolvimento, das seguintes áreas: educação, cultura, esporte, saúde pública, ciência e tecnologia, meio ambiente, e para mitigação e adaptação às mudanças climáticas (art. 47 da Lei n. 12.351/2010).

No artigo seguinte (art. 48), são expostos os objetivos do Fundo Social, quais sejam: I - constituir poupança pública de longo prazo com base nas receitas auferidas pela União; II - oferecer fonte de recursos para o desenvolvimento social e regional, na forma prevista no art. 47; e III - mitigar as flutuações de renda e de preços na economia nacional, decorrentes das variaçôes na renda gerada pelas atividades de produção e exploração de petróleo e de outros recursos não renováveis.

Serão analisadas em detalhes as características que informam o Fundo Social, notadamente a sua finalidade intergeracional, no capítulo seguinte, tendo em vista tratar-se de tema afeto muito mais ao uso das receitas petrolíferas do que a sua partilha. 